\title{
Comparison of Outcome and Success Rate of Onlay Island Flap and Dorsal Inlay Graft in Hypospadias Reconstruction: A Prospective Study
}

This article was published in the following Dove Press journal: Research and Reports in Urology

\author{
Johannes Aritonang \\ Arry Rodjani (D) \\ Irfan Wahyudi (D) \\ Gerhard Reinaldi Situmorang (D) \\ Department of Urology, Cipto \\ Mangunkusumo General Referral \\ Hospital, Faculty of Medicine, Universitas \\ Indonesia, Jakarta, Indonesia
}

Correspondence: Gerhard Reinaldi

Situmorang

Department of Urology, Cipto

Mangunkusumo General Referral

Hospital, Faculty of Medicine, Universitas

Indonesia, Jakarta, Indonesia

Tel +62 813 10303083

Email gr.urorscm@gmail.com
Background: Chordee correction, urethroplasty, and tissue reconstruction are performed to correct and retain standard functionality of the penis in hypospadias. Conventional reconstruction techniques, such as onlay island flap and the dorsal inlay graft, can be performed based on the classification of hypospadias. However, the outcomes and complication rates have not been widely studied. Thus, we aimed to provide preliminary evidence regarding the efficacy and safety of both approaches in hypospadias reconstruction.

Patients and Methods: A prospective study with two time evaluations of 14 and 180 days post-operatively was performed at the Urology outpatient clinic from October 2014 to September 2019. A proportion comparison of success rate, time to the complication, operation time, catheterization duration, uroflowmetry parameter post-surgery, and mean scores comparison of PPPS were measured as the intended outcomes.

Results: In a total of 59 pediatric hypospadias, patients who had undergone reconstruction are included in this study. Higher subjects' age and severe chordee severity were more common in the dorsal inlay graft group (age=7.50 [1-26] months; severe chordee $45.8 \%$ ) compared to the onlay island flap group (age=4.0 [1-67] months; severe chordee $31.4 \%$ ), both groups showed similar satisfaction regarding meatal shape and position $(P=0.618)$, glands shape $(P=0.324)$, penile skin shape $(P=0.489)$, and general cosmetic appearance $(P=0.526)$. Complication occurrence and time to complication duration of both groups were also not statistically significant $(P=0.464$ and $P=0.413)$. There are no significant differences in $\mathrm{Q}_{\max }, \mathrm{Q}_{\text {mean }}$, voided volume, and PVR of both groups $(P=0.125,0.136$, $0.076,0.260$, respectively). Significant differences in operation times and catheterization duration are found in this study $(P<0001)$.

Conclusion: Outcome evaluation regarding functional, complication and patient satisfaction comparing onlay flap and dorsal inlay graft for hypospadias patients is scarce. This study found that both procedures can be considered safe with comparable incidence of complications.

Keywords: chordee correction, urethroplasty, uroflowmetry

\section{Introduction}

Hypospadias is a congenital external genital disorder most commonly affecting boys, with an incidence which varies between 1:200 and 1:300. Based on the classification of pediatric urology guidelines by the European Association of Urology (EAU) in 2020, hypospadias can be classified as: distal or anterior; intermediate or middle; and proximal or posterior. ${ }^{1}$ In most cases, hypospadias in children are associated with three anomalies on the penis, namely the ventral meatus, chordee, and dorsal preputial sheath with a ventral preputium deficit. ${ }^{2}$ 
The surgical procedure has three characteristics, namely chordee correction, urethroplasty, and tissue reconstruction that forms part of the ventral radius of the penis (glans, corpus spongiosum, and skin that aims to improve the cosmetic appearance of the penis). ${ }^{3}$ Several hypospadias reconstruction techniques can be performed based on the classification of the hypospadias. The two most commonly used techniques are the onlay island flap and the dorsal inlay graft.

The onlay island flap technique developed from the transverse preputial island flap (TPIF) technique, which was first reported by Ducket et $\mathrm{al}^{4}$ in 1980 . Two previous concepts by Elder et al and Koyanagi et al were adapted by Mollard et $\mathrm{al}^{5}$ to developed this Onlay island flap technique, which is initially used for distal hypospadias and preservation of the urethral plate. This technique has been successfully proven in reconstructing hypospadias with chordees. This method is carried out by flapping the fascia dartos, suturing, and finally covered with the skin of the penis on the outside. Meanwhile, the dorsal inlay graft technique aims to maintain the urethral plate and expand the healthy surface area of the epithelium. ${ }^{6}$ In addition, this technique does not leave a new urethra (neourethra) caused by a long duration of re-epithelialization. Further, extension from the incision to the neomeatus at the tip of the glans can also be carried out in this technique. ${ }^{4}$ This maneuver is very helpful in hypospadias with flat glans, and can be performed in hypospadias either with or without chordee, by reducing the risk of stenosis. ${ }^{7}$ Regarding the advantages and disadvantages between both techniques, the researchers are determined to compare the outcome and success rate of both procedures.

\section{Patients and Methods}

A prospective study of 59 patients with two times evaluation (14 and 180 days post-operatively) was performed at the Urology outpatient clinic in Cipto Mangunkusumo General Referral Hospital, Jakarta from October 2014 to September 2019. Samples are recruited in a total sampling manner and allocated into two different technique groups based on indication and operator decision: onlay island flap and dorsal inlay graft. Surgical indications for the island onlay and the dorsal inlay are in the cases of proximal or distal hypospadias, narrow urethral plate, and moderate-severe chordee. However, in several patients with a wide urethral plate, the dorsal inlay flap was used due to fibrotic tissue and previous surgery history. As a result, the old urethral plate was not used, excised, and a new urethral plate was made using an inlay graft. Only pediatric hypospadias patients aged $<18$ years who underwent reconstruction for the first time with none to mild, moderate, or severe chordee, ventral curvature $\leq 30^{\circ}$, and with narrow or wide urethral plate were included in this study. The penile curvature and urethral plate was assessed pre- and intra-operatively. The urethral plate was pre-operatively evaluated with physical and supporting inspection, while pre-operative assessment of degree was used for penile curvature goniometer. After that, both the penile curvature and urethral plate were confirmed intraoperatively. Surgeries were performed by experienced pediatric urology consultants who regularly performed both techniques.

Patients' characteristics observed in this study include age, type of hypospadias, and concomitant abnormalities (chordee, penoscrotal transposition, bifid scrotum, undescended testis, urethral stricture). Outcomes measured in this study include functional outcome of maximum flow $(\mathrm{mL} / \mathrm{s})$ measured during uroflowmetry (180 days postoperatively), proportion comparison of success rate, and mean scores comparison of patient satisfaction index between both groups. Success rate was measured by the absence of post-operative complications during evaluation, while the satisfaction index was measured using the pediatric penile perception screening method (PPPS). ${ }^{8,9}$ Patient identity and pediatric perception screening method were filled in by the parents. Data regarding uroflowmetry result, post-operative complication evaluation, and reconstruction technique were obtained by the researchers.

\section{Surgical Technique}

In the onlay island flap technique, the patient was in a supine position with general and caudal anesthesia. After that, the chordae, curvature, urethral plate, and dorsal hood were examined for further steps. The transversal flap was taken from the preputial skin with one side continuously sutured into the edge of the urethral plate, while the other side was interruptedly sutured, both using polydioxanone (PDS). A 6-Fr silastic stent was used for guiding and applied on neourethra to be rolled into a tube (tubularization). The second layer was made using subcutaneous tissues from the preputial flaps. Furthermore, glanuloplasty was implemented before the tip of the distal flap was sutured into the penile glans. The outer skin was interruptedly sutured with PDS. Further, the bleeding and scar were controlled and covered with topical antibiotics 
and sterile gauze. In addition, the stent was removed after 7 days.

Similar to the previous technique, the dorsal inlay graft technique was performed after reexamining the patient in supine position under general and caudal anesthesia. Before conducting the surgery, informed consent was also carried out to determine which technique would be performed. If severe chordee, narrow urethral plate, and proximal type of hypospadias were explored during physical examination, this technique became preferable compared to another one. In addition, history of previous hypospadias repair was also considered to apply this technique. This technique will take the graft, which was previously measured and harvested from the inner prepuce. Then, the graft was defatted and sutured onto the incised urethral plate. A 6-Fr silastic stent was also applied for tubularization in one stage urethroplasty. A vascularized tunica vaginalis was used to be the second layer. Further, the raw surface was covered by interrupted suture using PDS, and the stent was removed after 14 days.

\section{Statistical Analysis}

Descriptive analysis was performed using SPSS version 23.0. Patient characteristics were analyzed using chisquare test. Comparison of functional outcomes (maximum flow observed during uroflowmetry), success and complications rates and satisfaction indices between hypospadias reconstruction techniques (Onlay Island Flap/Dorsal Inlay Graft) were calculated using the Chisquare or Mann-Whitney test. Independent $t$-test was performed to calculate the duration of catheterization and operation time.

\section{Ethical Permission}

This study was performed under ethical review and approval from The Ethics Committee of Faculty Medicine University Indonesia and Ciptomangunkusumo Hospital corresponding to ethical approval number 58/ UN2.F1/ETIK/I/2018.

\section{Informed Consent}

All study subjects who participated in this study were properly consented and documented with a standard informed consent form based on ethical guidelines from The Ethics Committee of Faculty of Medicine University Indonesia and Ciptomangunkusumo Hospital. Parental or legal consent was obtained from all patients under 18 years old. This study also complied with the Declaration of Helsinki.

\section{Results}

A total of 59 pediatric hypospadias patients who had undergone reconstruction at Cipto Mangunkusumo General Referral Hospital, Jakarta are included in this study. Of the 59 subjects included, we gathered 35 subjects as the onlay island flap arm and the remaining 24 as the dorsal inlay graft arm (59.3\% and $40.7 \%$, respectively). The pre-operative, post-operative, and 1 month postoperative clinical appearance of island onlay flap patients are described in Figure 1. Normality test revealed nonparametric distribution for age, for which median was used to describe both groups. Chordee severity was divided into three categories: none-to-mild, moderate, and severe. Most of the cases were classified into the moderate chordae $(50.8 \%)$, followed by severe and none-to-mild $(37.3 \%$ and $11.9 \%$ ). Hypospadias type was also documented according to the EAU classification of anterior, middle, and posterior/proximal of the penis. On all the study subjects, 17 of 59 subjects $(28.8 \%)$ were categorized with anterior hypospadias, while 14 (23.7\%) and $28(47.5 \%)$ were categorized with middle and posterior hypospadias, respectively. A wide urethral plate was observed in 31 $(52.5 \%)$ of 59 subjects, while the remaining were considered narrow. Detailed proportions in both of the groups for chordae severity, type of hypospadias, and urethral plate size are described in Table 1.

During follow-up evaluation, a standardized PPPS questionnaire was utilized which documented patients' satisfaction on four aspects of outcome including position and meatal position, glands shape, penile skin shape, and general cosmetic appearance. There is no significant difference between both only island and dorsal inlay flap in all PPPS questionnaire parameter $(P=0.125,0.136,0.076$, and 0.260 , respectively). On both arms, meatal shape and position, gland shape, and penile skin shape turns out to be satisfactory for most subjects. While most of the subjects from both techniques are dissatisfied about the general cosmetic appearance post-intervention. In Table 2, the details spread out of PPPS in both of the groups are explained. Furthermore, the median observed times to complication on onlay island flap and dorsal inlay groups were 19 and 14 months. There is no statistical significance between both groups' complication $(P=0.413)$.

Five $(20.8 \%)$ complication occurrences were observed in the dorsal inlay groups which were due to 


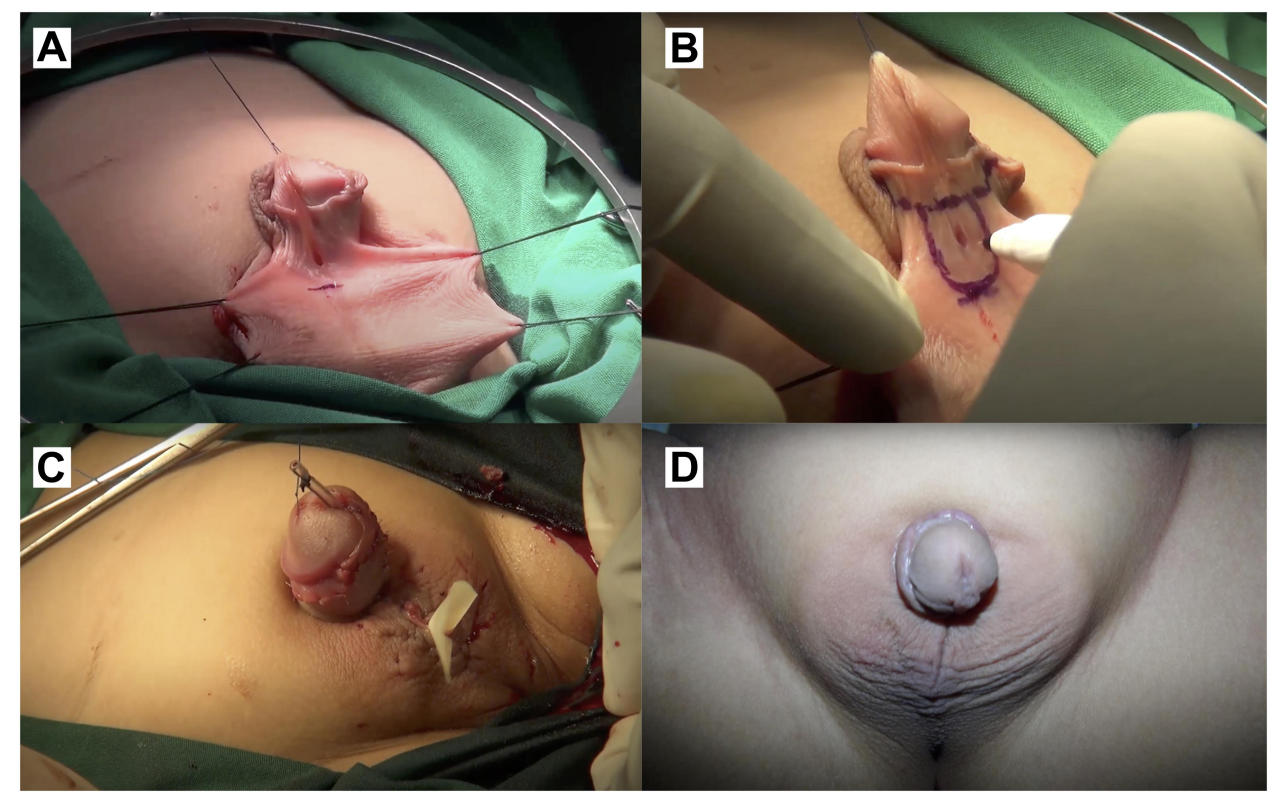

Figure I Island onlay flap technique. (A) Patient pre-operative proximal hypospadias clinical appearance. (B) Surgical site marking on the patient penis. (C) Post-operative clinical appearance of patient. (D) One-month post-operative follow-up of the patient.

urethrocutaneous fistula (two; 8.3\%), urethral stricture (one; $4.2 \%$ ), and failed hypospadias due to fibrotic tissue (two; 8.3\%). Urethrocutaneous fistula were repaired by redo urethroplasty or excision and primary closure. Stricture on dorsal inlay groups were treated using

Table I Subjects Characteristics

\begin{tabular}{|c|c|c|c|c|}
\hline Variables & $\begin{array}{l}\text { Onlay } \\
\text { Island } \\
\text { Flap } \\
(n=35 ; \\
59.3 \%)\end{array}$ & $\begin{array}{l}\text { Dorsal } \\
\text { Inlay } \\
\text { Graft } \\
(n=24 ; \\
40.7 \%)\end{array}$ & $\begin{array}{l}\begin{array}{l}\text { Total } \\
(n=59 ; \\
100 \%)\end{array}\end{array}$ & $P$-value \\
\hline Age & $4.0(I-67)$ & $7.50(I-26)$ & $\begin{array}{l}4.0 \\
(1.0-67.0)\end{array}$ & \\
\hline \multicolumn{5}{|c|}{ Chordee Severity } \\
\hline $\begin{array}{l}\text { None-to- } \\
\text { Mild } \\
\text { Moderate } \\
\text { Severe }\end{array}$ & $\begin{array}{l}3(8.6 \%) \\
21(60 \%) \\
\mathrm{II}(3 \mathrm{I} .4)\end{array}$ & $\begin{array}{l}4(16.7) \\
9(37.5) \\
\text { II }(45.8)\end{array}$ & $\begin{array}{l}7(11.9) \\
30(50.8) \\
22(37.3)\end{array}$ & 0.002 \\
\hline \multicolumn{5}{|c|}{ Urethral Plate Size } \\
\hline $\begin{array}{l}\text { Narrow } \\
\text { Wide }\end{array}$ & $\begin{array}{l}17(48.6) \\
18(51.4)\end{array}$ & $\begin{array}{l}\text { II (45.8) } \\
\text { I3 (54.2) }\end{array}$ & $\begin{array}{l}28(47.5) \\
31(52.5)\end{array}$ & 0.839 \\
\hline \multicolumn{5}{|c|}{ Type of Hypospadias } \\
\hline $\begin{array}{l}\text { Anterior } \\
\text { Middle } \\
\text { Posterior }\end{array}$ & $\begin{array}{l}\text { II (31.4) } \\
9(25.7) \\
\text { I5 (42.9) }\end{array}$ & $\begin{array}{l}6(25) \\
5(20.8) \\
13(53.2)\end{array}$ & $\begin{array}{l}17(28.8) \\
14(23.7) \\
28(47.5)\end{array}$ & 0.694 \\
\hline
\end{tabular}

Notes: $P<0.002$. There is a significantly statistical difference between the two groups. urethroplasty with full thickness skin graft. Redo urethroplasty with excision of fibrotic tissue were done on both failed hypospadias repair. In the onlay island flap group, four occurrences of complication (11.4\%) were observed, which consisted of two urethrocunateous fistula cases $(5.7 \%)$ and two failed hypospadias (5.7\%), with one case suspected with balanitis xerotica obliterans (BXO). For urethrocutaneous fistula on onlay island flap group, redo urethroplasty and fistulectomy were conducted while penile reconstruction and redo urethroplasty were performed to treat failed hypospadias cases in this group.

Uroflowmetry examinations were performed after both hypospadias interventional surgery. There is no statistical difference in the $\mathrm{Q}_{\max }, \mathrm{Q}_{\text {mean }}$, voided volume, and postvoid residual (PVR) between the onlay island flap and dorsal inlay graft (Table 3 ). The time needed to perform both techniques was recorded. Onlay island flap provided a shorter operation time and catheterization compared to dorsal inlay graft $(169.2 \pm 28.6,5.3 \pm 0.6$ vs $254.4 \pm 40.1,7.1$ $\pm 0.3 ; P<0.001)$.

\section{Discussion}

This study has been able to gather a total of 59 hypospadias cases in the course of 5 years during the study intended duration. Since hypospadias occurrence is approximated to be 1:200 to 1:300 among newborn males, the total subjects in this study can be considered smaller than expected, since the number of newborns in 
Table 2 Outcome Comparison Between Onlay Island Flap and Dorsal Inlay Graft

\begin{tabular}{|c|c|c|c|}
\hline Outcome Variables & $\begin{array}{l}\text { Onlay Island } \\
\text { Flap }\end{array}$ & $\begin{array}{l}\text { Dorsal Inlay } \\
\text { Graft }\end{array}$ & $P$-value \\
\hline \multicolumn{4}{|l|}{ Patient Satisfaction } \\
\hline $\begin{array}{l}\text { Meatal Shape and } \\
\text { Position } \\
\text { Very Dissatisfied } \\
\text { Dissatisfied } \\
\text { Satisfied } \\
\text { Very Satisfied }\end{array}$ & $\begin{array}{l}0(0) \\
4(11.4) \\
22(62.9) \\
9(25.7)\end{array}$ & $\begin{array}{l}0(0) \\
4(16.7) \\
15(62.5) \\
5(20.8)\end{array}$ & 0.618 \\
\hline $\begin{array}{l}\text { Glands Shape } \\
\text { Very Dissatisfied } \\
\text { Dissatisfied } \\
\text { Satisfied } \\
\text { Very Satisfied }\end{array}$ & $\begin{array}{l}0(0) \\
2(5.7) \\
23(65.7) \\
10(28.6)\end{array}$ & $\begin{array}{l}\text { I }(4.2) \\
3(12.5) \\
14(58.3) \\
7(29.2)\end{array}$ & 0.324 \\
\hline $\begin{array}{l}\text { Penile Skin Shape } \\
\text { Very Dissatisfied } \\
\text { Dissatisfied } \\
\text { Satisfied } \\
\text { Very Satisfied }\end{array}$ & $\begin{array}{l}0(0) \\
4(11.4) \\
23(65.7) \\
8(22.9)\end{array}$ & $\begin{array}{l}0(0) \\
2(8.3) 16 \\
(66.7) \\
6(25)\end{array}$ & 0.489 \\
\hline $\begin{array}{l}\text { General Cosmetic } \\
\text { Appearance } \\
\text { Very Dissatisfied } \\
\text { Dissatisfied } \\
\text { Satisfied } \\
\text { Very Satisfied }\end{array}$ & $\begin{array}{l}0(0) \\
5(14.3) \\
25(7 \mid .5) \\
5(14.3)\end{array}$ & $\begin{array}{l}0(0) \\
3(12.5) \\
15(62.5) \\
6(25)\end{array}$ & 0.526 \\
\hline \multicolumn{4}{|c|}{ Complication Occurrence } \\
\hline $\begin{array}{l}\text { Yes } \\
\text { No }\end{array}$ & $\begin{array}{l}4(11.4) \\
31(88.6)\end{array}$ & $\begin{array}{l}5(20.8) \\
19(79.2)\end{array}$ & 0.464 \\
\hline \multicolumn{4}{|c|}{ Time to Complication } \\
\hline $\begin{array}{l}\text { Median Months } \\
\text { (Min-Max) }\end{array}$ & $19(10-28)$ & $14(6-2 \mid)$ & 0.413 \\
\hline
\end{tabular}

Jakarta each year is estimated to be around 200,000. The incidence might be lower due to several factors, such as the implementation of universal health coverage and the mandatory referral system in Indonesia since 2014. ${ }^{10}$ Starting from a similar period which coincided with this study time frame, we observed a decreased number of hypospadias cases treated in several referral centers in Indonesia. However, other factors such as patient care seeking behavior and screening programs might play a significant role in the incidence number of hypospadias. Springer $^{8}$ described their finding on the prevalence of hypospadias and found the number varies greatly, especially in Asian countries, due to the different healthcare
Table 3 Uroflowmetry Outcome, Operation Time, and Duration of Catheterization Comparison Between Onlay Island Flap and Dorsal Inlay Graft

\begin{tabular}{|c|c|c|c|}
\hline Outcome Variable & $\begin{array}{l}\text { Onlay } \\
\text { Island } \\
\text { Flap }\end{array}$ & $\begin{array}{l}\text { Dorsal } \\
\text { Inlay } \\
\text { Graft }\end{array}$ & $P$-value \\
\hline \multicolumn{4}{|l|}{ Uroflowmetry Result } \\
\hline $\mathrm{Q}_{\max }$ & $\begin{array}{l}6.2 \\
(4.2-22.4)\end{array}$ & $\begin{array}{l}10.1 \\
(4.8-22.8)\end{array}$ & 0.125 \\
\hline $\mathrm{Q}_{\text {mean }}$ & $\begin{array}{l}3.9 \\
(2.4-12.1)\end{array}$ & $5.1(3-13)$ & 0.136 \\
\hline Voided volume & $\begin{array}{l}48 \\
(28-247)\end{array}$ & $\begin{array}{l}64 \\
(33-337)\end{array}$ & 0.076 \\
\hline PVR & $2(0-26.9)$ & $2.7(0-25.7)$ & 0.260 \\
\hline \multicolumn{4}{|l|}{ Operation Time } \\
\hline $\begin{array}{l}\text { Mean of operation time } \\
\text { (minutes) }\end{array}$ & $169.2 \pm 28.6$ & $254.4 \pm 40.1$ & $<0.001$ \\
\hline \multicolumn{4}{|c|}{ Duration of Catheterization } \\
\hline $\begin{array}{l}\text { Mean of duration of } \\
\text { catheterization (minutes) }\end{array}$ & $5.3 \pm 0.6$ & $7.1 \pm 0.3$ & $<0.001$ \\
\hline
\end{tabular}

Notes: $P<0.00$ I. There is significant statistical difference between two groups.

systems. Since Indonesia has implemented a screening program for newborns, infants, and school-age, the majority of hypospadias cases should be recognized from an early age. However, Pratiwi and Basuk ${ }^{11}$ previously mentioned in their study that health seeking behavior in Indonesia can be considered low, especially in the rural area where midwives play a huge role on educating the family to seek medical treatment.

Of the 59 subjects in this study, we gathered 35 subjects on onlay island flap group and 24 subjects on dorsal inlay graft group. There is a median difference in which the dorsal inlay group had a higher period of observed complication occurrence than the onlay group (7.5 [1-26] months vs 4 [1-67] months) but both numbers can be considered early since another study with a similar time frame and population conducted by Nerli et $\mathrm{al}^{12}$ observed a higher number of age mean $48.83 \pm 8.29$ (range=36-67) months when undergoing reconstructive surgery. Comparing the proportion based on chordee severity, we observed a similar tendency of patients treated on both groups to be categorized on moderate-to-severe (proportion of moderate and severe chordee of $60 \%$ and $31.4 \%$ on onlay island graft group and $37.5 \%$ and $45.8 \%$ on dorsal 
inlay group, respectively). This aligned well with hypospadias types observed in this study, which mainly consist of posterior/proximal type on both groups $(42.9 \%$ and $53.2 \%$ on onlay island flap and dorsal inlay group, respectively) which is similar to several studies. ${ }^{13,14}$ Onlay island flap technique is commonly used in both minimal or moderate chordee and severe chordees in our center. After performing penile degloving, orthoplasty and urethroplasty by transversal flapping in preputial skin were also performed. Urethral plate observed on both intervention groups returned almost to a 1:1 ratio between narrow and wide urethral plate and both groups did not show a significant difference during statistical analysis.

We presented three outcomes of complication rate, uroflowmetry result, and patient satisfactory score using the pediatric penile perception screening method. Complications following hypospadias repair are common and include stricture, fistula, and diverticulum formation. During the past decades, the most common technique of proximal hypospadias repair involved the use of a vascularized transverse preputial island flap as a tubularized neourethra or as a ventral onlay over an intact urethral plate. ${ }^{15}$ The results of these procedures were satisfactory and improved over time. From our study, we documented five complication occurrences in the dorsal inlay graft group and four occurrences in the onlay island flap group during the study time frame on follow-up of 180 days after the surgery. One patient in this occurrence only comprises of $11.4 \%$ group subjects undergone onlay island flap and $20.8 \%$ of subjects undergone dorsal inlay graft. These incidences can be considered within the normal limit, since observations by Sheng et $\mathrm{al}^{16}$ showed that complications from hypospadias repair may comprise up to $32.5 \%$ of all treated patients. Time from hypospadias repair to complication occurrence observed in this study also aligns well with the observations of Sheng et al, ${ }^{16}$ which mostly occurred during 6-24 months of follow-up. However, this number can vary wildly from different operators and centers. Findings by Asanuma et $\mathrm{al}^{17}$ seemed to confirm this idea which observed fistula occurrence in oneof 28 subjects at a mean of 22 months follow-up. Further statistical analysis on complication occurrence and time to complication for both intervention groups yielded an insignificant difference. These findings may indicate that one approach does not have higher correlation with complication occurrences nor time to occurrences compared with another intervention group.
We compared both groups' satisfaction and documented the result as shown in Table 2. From Mann-Whitney analysis, most patient reported satisfactory results in both groups. Proportion comparison between both groups for meatal shape and position aspect show an insignificant statistical difference $(P$-value $=0.618)$ between both groups, implying that both techniques produce a similar satisfactory position and meatal position outcome for the patients. Between both intervention arms, the majority of subjects found satisfactory or very satisfactory gland shape outcome after undergoing the procedure. Subjects replying as satisfied and very satisfied on the PPPS questionnaire comprised $94.3 \%$ and $87.5 \%$ in the onlay island flap and dorsal inlay graft group, respectively, with a $P$-value of 0.324 . Similar results were observed for penile skin shape and general cosmetic appearance during evaluation with a $P$-value of 0.489 and 0.526 , respectively. This is aligned with a study conducted by Weber et al, ${ }^{18}$ which compared the PPPS score from a normal population and hypospadias patients from age 7-17 years. The study found that, compared to controls, there are no differences of penile shape perception between both groups. Another similar study conducted by Schönbucher et al ${ }^{19}$ also showed similar results where control groups and hypospadias patients showed no difference and both groups perceived a high level of satisfaction. A long-term follow-up by Fraumann et $\mathrm{al}^{20}$ found that even after long-term follow-up, $85 \%$ of 18-30 years old hypospadias boys also showed very positive satisfaction, although $35 \%$ of them reported residual curvature. Another study by Jones et al reported that almost $31.4 \%$ of hypospadias patient perceived their penis looked abnormal, but, despite this condition, $81 \%$ were satisfied with the overall cosmetic status and it did not affect their body image, which confirms our findings. Although we did not compare with a normal population as a control, our findings show a high level of satisfaction between both intervention groups and, thus, aligned with the goal of the reconstruction conducted.

This study also compares the uroflowmetry parameter of $\mathrm{Q}_{\max }, \mathrm{Qv}_{\text {olume }}$, voided volume, and PVR between two interventional groups. There are no significant differences in all of those parameters between two groups $(P=0.125$, $0.136,0.076,0.260$, respectively). This result suggested that both the onlay island flap and dorsal inlay graft produced good and adequate uroflowmetry parameters. Moreover, operation time also took account as a parameter to see the differences between two techniques. This study operative duration of dorsal inlay graft is 
espoused to Asanuma et al's ${ }^{17}$ result of 200 minutes (range $=154-249$ minutes). The onlay island flap required a shorter period due to its single stage procedure (169.2 \pm 28.6 minutes). The duration of catheterization is also important to be observed due to its connection to urinary tract and systemic infections. Shorter catheterization duration is observed in onlay island flap groups $(5.3 \pm 0.6$ vs 7.1 $\pm 0.3, P<0.001)$. Therefore, time efficiency of onlay island flap techniques became a reason for the urologist to prioritize or choose this technique compared to the dorsal inlay graft for hypospadias management.

Our analysis is subject to some limitations. First, this is a prospective study. We did not perform any experimental intervention in the patient. The classification of patient intervention is then determined solely based on the indication and discretion by the operator. Second, in the patient group determination there is no randomization process which increases the likelihood of bias. Moreover, there is a statistically significant gap in the patient characteristics between two groups in the chordee severity, which means the baseline characteristics are not sufficiently standardized. Some cases have been monitored for 180 days in our study. There is, however, a small share of patients that were followed only by 3 months. Among such categories, there is a chance that the patient is not present with any complications such as strictures or fistula due to lack of a follow-up period.

\section{Conclusion}

Outcome evaluations regarding functional, complication, and patient satisfaction comparing onlay flap and dorsal inlay graft for hypospadias patients are scarce. This study found that both procedures can be considered safe with comparable incidence of complications. Because hypospadias surgery is a constantly evolving art, long-term studies (into adulthood) will continue to be important and will need to be repeated for each new procedure developed if surgeons are to continue to provide an honest and meaningful account of their results.

\section{Funding}

Funding was received from our institution Faculty Medicine University Indonesia, Ciptomangunkusumo Hospital, Jakarta, as an operational research grant. We can confirm that there was no external organization or company sponsorship in this study.

\section{Disclosure}

The authors declare no conflicts of interest for this work.

\section{References}

1. Turk C, Donaldson F, Neissius A, et al. EAU Guidelines on Paediatric Urology. The Netherlands: EAU Guidelines Office; 2020.

2. Hayashi Y, Sasaki S, Kojima Y, et al. The one-stage repair of moderately severe hypospadias using a transverse preputial tubulurized island flap. Int J Urol. 2001;8(4):165-170. doi:10.1046/j.14422042.2001.00275.x

3. Shukla AR, Patel RP, Canning DA. The 2-stage hypospadias repair. Is it a misnomer? J Urol. 2004;172(4 Part 2):1714-6; discussion 6. doi:10.1097/01.ju.0000138926.26530.f9

4. Duckett JW. Transverse preputial island flap technique for repair of severe hypospadias. 1980. J Urol. 2002;167(2 Pt 2):1179-1183.

5. Acimi S. Proximal hypospadias: effect of urethral plate mobilization on release of chordee. Urology. 2012;80(4):894-898. doi:10.1016/j. urology.2012.06.050

6. Kolon TF, Gonzales ET. The dorsal inlay graft for hypospadias repair. J Urol. 2000;163(6):1941-1943. doi:10.1016/S0022-5347 (05)67603-3

7. Snodgrass WT, Shukla AR, Canning DA. Hypospadias. UK: Informa Healthcare; 2007.

8. Springer A. Assessment of outcome in hypospadias surgery - a review. Front Pediatr. 2014;2:2. doi:10.3389/fped.2014.00002

9. Hussein NS, Bin Abd Samat S, Abdullah MAK, Gorhar MG. Cosmetic and functional outcomes of two-stage hypospadias repair: an objective scoring evaluation and uroflowmetry. Turk $J$ Urol. 2013;39(2):90-95. doi:10.5152/tud.2013.015

10. Rina A, Dartanto T, Sitompul R, et al. Universal health coverage in Indonesia: concept, progress, and challenges. Lancet. 2018;393 (10166):75-102. doi:10.1016/s0140-6736(18)31647-7

11. Pratiwi NL, Basuk H. Health seeking behavior and family planning services accessibility in Indonesia. Bull Health Syst Res. 2014;17 (1):45-53.

12. Nerli RB, Guntaka A, Patil RA, Patne PB. Dorsal inlay inner preputial graft for primary hypospadias repair. Afr J Paediatr Surg. 2014;11(2):105-108. doi:10.4103/0189-6725.132789

13. Braga LH, Pippi Salle JL, Dave S, Bagli DJ, Lorenzo AJ, Khoury AE. Outcome analysis of severe chordee correction using tunica vaginalis as a flap in boys with proximal hypospadias. $J$ Urol. 2007;178(4S):1693-1697. doi:10.1016/j.juro.2007.03.166

14. Kajbafzadeh AM, Arshadi H, Payabvash S, Salmasi AH, NajjaranTousi V, Sahebpor AR. Proximal hypospadias with severe chordee: single stage repair using corporeal tunica vaginalis free graft. $J$ Urol. 2007;178(3):1036-1042. doi:10.1016/j.juro.2007.05.062

15. Adams J, Bracka A. Reconstructive surgery for hypospadias: a systematic review of long-term patient satisfaction with cosmetic outcomes. Indian J Urol. 2016;32(2):93-102. doi:10.4103/0970-1591.179178

16. Sheng X, Xu D, Wu Y, Yu Y, Chen J, Qi J. The risk factors of urethrocutaneous fistula after hypospadias surgery in the youth population. BMC Urol. 2018;18(1):64-70. doi:10.1186/s12894-018-0366-z

17. Asanuma H, Satoh H, Shishido S. Dorsal inlay graft urethroplasty for primary hypospadiac repair. Int $J$ Urol. 2007;14(1):43-47. doi:10.1111/j.1442-2042.2006.01662.x

18. Weber DM, Schönbucher VB, Landolt MA, Gobet R. The pediatric penile perception score: an instrument for patient self-assessment and surgeon evaluation after hypospadias repair. $J$ Urol. 2008;180 (3):1080-1084. doi:10.1016/j.juro.2008.05.060

19. Schönbucher VB, Landolt MA, Gobet R, Weber DM. Psychosexual development of children and adolescents with hypospadias. J Sex Med. 2008;5(6):1365-1373. doi:10.1111/ j.1743-6109.2007.00742.x

20. Fraumann SA, Stephany HA, Clayton DB, et al. Long-term follow-up of children who underwent severe hypospadias repair using an online survey with validated questionnaires. J Pediatr Urol. 2014;10 (3):446-450. doi:10.1016/j.jpurol.2014.01.015 


\section{Publish your work in this journal}

Research and Reports in Urology is an international, peer-reviewed, open access journal publishing original research, reports, editorials, reviews and commentaries on all aspects of adult and pediatric urology in the clinic and laboratory including the following topics: Pathology, pathophysiology of urological disease; Investigation and treatment of urological disease; Pharmacology of drugs used for the treatment of urological disease. The manuscript management system is completely online and includes a very quick and fair peer-review system, which is all easy to use. Visit http://www.dovepress.com/ testimonials.php to read real quotes from published authors.

Submit your manuscript here: https://www.dovepress.com/research-and-reports-in-urology-journal 